\title{
Cánepa Koch, Gisela e Ingrid Kummels (eds.). Photography in Latin America: Images and Identities Across Time and Space. Bielefeld: Transcript Verlag, 2016, 242 pp.
}

Este es un libro de historias sobre cómo conjuntos de fotografías, al cambiar de ámbitos a través del tiempo y del espacio, al entrar y salir de ciertas estructuras de archivo, al cambiar de contextos institucionales y políticos, cambian lo que son, lo que muestran, emergiendo como evidencias de cosas o eventos muchas veces distintos y lejanos de las intenciones de sus creadores. Al ser vistas y usadas en nuevos espacios y tiempos, muchas veces luego de permanecer almacenadas e invisibles por largos años, estas imágenes adquieren nuevas vidas en los diálogos que establecen con nuevas miradas.

En estas reflexiones, los trabajos de este libro combinan dos tipos de fascinación muy distintas alrededor de la fotografía como práctica y tecnología. En primer lugar, tenemos el particular interés que provocan las fotografías que nos llegan del pasado, las fotografías antiguas que emergen de colecciones de museos $\mathrm{y}$ archivos etnográficos, de antiguos álbumes familiares asociados a distinto detalle, muchas veces muy poco, de información no visual. En segundo lugar, los distintos artículos que componen este libro también se interesan por el no menos fascinante fenómeno contemporáneo en el que las tecnologías, al facilitar de una manera sorprendente la producción y circulación de fotografías, han hecho de estas algo no solo ubicuo sino también fugaz, y hasta banal.

Los distintos artículos del libro comparten estrategias de investigación similares que prestan atención en primer lugar al contexto de producción y circulación inicial de las fotos, luego al contexto o contextos donde estas fueron archivadas, y finalmente, a los nuevos contextos de circulación e interpretación contemporáneos.

Las historias que analizan los diferentes capítulos están organizadas cronológicamente e incluyen casos de fotos que fueron tomadas hacia finales del siglo XIX hasta aquellas que provienen de las décadas de 1980 y 1990. Michael Krauss estudia la producción de fotografías etnográficas a fines del siglo XIX en la Amazonía colombiana, brasileña y peruana, a través de una colección del Museo de Berlín. Gisela Cánepa reconstruye la esforzada actividad fotográfica y la agenda del ingeniero Brüning también a fines del siglo XIX en la costa norte peruana. Analiza también los distintos contextos de archivamiento de sus fotografías en Alemania y la utilización contemporánea que estas vienen teniendo en procesos de emergencia de nuevos regionalismos y etnicidades en la costa norte. Aura Reyes 
estudia la producción fotográfica y las excavaciones del antropólogo alemán Preuss en Colombia, que forman parte de las colecciones de museos en Alemania y Suecia y que ahora se encuentran al centro de una disputa por su repatriación. La autora también discute los debates que las fotos de Preuss, que ella llevó en su trabajo de campo, desataron entre los Kogi, incluyendo la legitimidad de la práctica fotográfica de Preuss. Marian Petroni estudia cómo fotografías etnográficas producidas a mediados del siglo XX por el antropólogo Julio de la Fuente para mostrar el «continuum folk-urbano» en una comunidad zapoteca en México son apropiadas por los habitantes de esta misma comunidad como herramientas en su agenda etnopolítica. Ingrid Kummels analiza cómo fueron recibidas en 2014 las fotografías que el etnógrafo y activista Manfred Schäfer realizó en las décadas de 1970 y 1980 en la comunidad de Mareni en la Amazonia peruana. Recibidas por una comunidad ajena al uso cotidiano de fotografías, Kummels explica cómo estas son apropiadas de formas inesperadas en regímenes de valor claramente diferentes de aquellos usados por quienes viven familiarizados con la fotografía y cómo estas se articulan como herramientas políticas en su relación con el Estado, en un contexto en que la comunidad se recupera de los estragos del conflicto armado interno. Por su parte, Mercedes Figueroa analiza cómo, ante eventos dramáticos, ampliaciones de fotografías carné y de álbumes familiares se trasforman en dolorosos y efectivos elementos en la búsqueda de justicia por los familiares de personas desaparecidas en contextos de violencia política. Finalmente, María Eugenia Ulfe y Ximena Málaga elaboran sobre cómo las fotografías contenidas en álbumes familiares en un pueblo ayacuchano son recontextualizadas en un diálogo entre las etnógrafas y los residentes del pueblo, a través del cual estas pueden mostrar cómo en la década de 1980 la vida cotidiana continuaba paralela a los dramáticos eventos del conflicto armado interno que sucedieron en este pueblo, cuyo nombre - para muchos peruanos - es indesligable de este.

De este modo, los textos nos llevan por muchos lugares de Latinoamérica, así como a espacios fuera de esta, como museos y colecciones europeas. Adicionalmente, se presta atención etnográfica a colecciones alojadas en servidores de internet, permitiendo nuevas formas de circulación de estas imágenes.

Los textos que discuten las fotografías etnográficas reflexionan en torno a temas como la anonimidad de las personas fotografiadas que las construyen como tipos antes que como individuos. También sobre las tensiones en torno a la agencia, tanto de los etnógrafos/fotógrafos como de las personas fotografiadas y la política involucrada en la producción de fotografías etnográficas, y se cuestiona el localizar la agencia exclusivamente en el fotógrafo asumiendo pasividad en 
el o la fotografiada. Las fotografías etnográficas emergen, en la Amazonía por ejemplo, a través diversos arreglos, y una gran heterogeneidad de situaciones que siempre implican relaciones de poder en las cuales la agencia de los fotografiados no puede ser simplemente ignorada.

Un aspecto importante que cruza diferentes análisis es la reflexión en torno al archivamiento de estas colecciones. Los textos se refieren a diferentes situaciones: colecciones cuidadas por museos, archivos etnográficos que han sido guardados por los etnógrafos mismos o por sus familiares, álbumes familiares que han sido construidos teniendo en mente una audiencia y circulación restringida a la familia y a los amigos, así como las distintas formas como internet da accesibilidad y es un repositorio de fotografías reunidas en distintas formas, como por ejemplo, en la página web de un museo o en una página de Facebook. Estos diferentes tipos de archivos tienen consecuencias importantes en la localización de las fotografías, en quiénes pueden acceder a estas, cómo estas circulan, cómo su circulación está restringida o totalmente anulada. De esta forma, la estructura del archivo configura diferentes tipos de audiencias imponiendo particulares marcos de autoridad a través de los cuales se da la interpretación de qué es lo que se ve en estas fotografías y por qué estas son importantes. Incluso la aparente democratización del acceso a cierto tipo de imágenes que se da a través de plataformas como Facebook está asociada a nuevas formas de control y regimentación sobre cómo estas imágenes deben ser vistas.

Las nuevas formas de circulación y reapropiación a las que prestan atención los distintos capítulos también involucran una gran diversidad. En estas vemos cómo las fotografías etnográficas que fueron producidas como parte de un proyecto científico de descripción de «otros» culturales se trasforman en elementos cruciales en la construcción de nuevas identidades regionales y étnicas. Cómo los intentos de devolver fotografías etnográficas tomadas en la década de 1980 en las Amazonia peruana enfrentan paradojas difíciles de prever cuando la comunidad fotografiada hace más de dos décadas es confrontada con fotografías cuando estas no son parte de su forma de relacionarse consigo mismos ni con sus familiares, al tiempo que algunos líderes pronto empiezan a articular sus usos políticos. La colección elabora también sobre cómo colecciones que emergen de ámbitos familiares pueden tornarse en fotografías que se usan etnográficamente, cómo las fotografías familiares emergen para reconstruir la textura de la vida cotidiana de una comunidad que sufrió durante el conflicto armado interno, o cómo humildes fotografías carné se transforman no solo en índices de la ausencia de seres queridos sino también en elementos centrales en la lucha de estas familias por 
conseguir justicia frente a casos de desapariciones forzadas en el contexto del conflicto armado interno.

Ver una fotografía nos conecta a través de cadenas de causas y efectos a aquello que vemos en esta. Estas cadenas efectivamente nos ponen materialmente en contacto con esos eventos y con esas personas. Es en esa cadena de causas y efectos físicos, químicos y electrónicos en la que se funda la autoridad de la fotografía como índice de algo que realmente sucedió y así se presenta como una ventana al pasado. Lo que hace este libro es mostrarnos cómo, no obstante la certidumbre que tenemos sobre la existencia de esa conexión, del carácter de evidencia con el que tornamos nuestra mirada frente a las fotografias, lo que vemos en ellas depende en gran medida de las ideologías, instituciones, proyectos, preferencias estéticas que constituyen el contexto y el mirar a través de los cuales las fotografías cobran nuevas vidas. Cuando la cadena de causas y efectos que constituye una fotografía se engarza en diferentes contextos culturales, esta puede emerger como evidencia de realidades distintas, escapando tanto a las intenciones como a la imaginación de sus productores.

\section{Guillermo Salas Carreño \\ Pontificia Universidad Católica del Perú}

\section{Resumen}

Reseña brevemente los artículos de un compendio que analiza cómo conjuntos de fotografías, al cambiar de ámbitos a través del tiempo y del espacio, al entrar y salir de ciertas estructuras de archivo, al cambiar de contextos ideológicos y políticos, cambian lo que son, lo que muestran, emergiendo como evidencias de cosas o eventos distintos y lejanos a las intenciones de sus creadores. Palabras clave: reseña, fotografía, archivo fotográfico, fotografía etnográfica, nuevos contextos, nuevas miradas. 